\title{
Effect of Normal Pregnancy on Glucose Assimilation, Insulin and Non-Esterified Fatty Acids Levels
}

\author{
C. Picard, H. A. Ooms, E. Batasse et V. Conard
}

Laboratoire de Gynécologie Expérimentale (Pr P. O. Hubrnont) - Hôpital Universitaire Saint-Pierre - Laboratoires de Médecine Expérimentale (Pr P. Bastenra) et de Pathologie Générale (Pr V. ConaRD) - Université Libre de Bruxelles

\section{Received February 6, 1967}

Summary. Insulin and non-esterified fatty acid (NEFA) levels were determined following a rapid intravenous injection of glucose in a control group as well as in early and late normal pregnancy. The peak level of plasma insulin occuring within the first six minutes of the test was higher in early pregnancy than in the control group. This difference thereafter was blunted. - The highest insulinic response was obtained in late pregnancy and was maintained throughout the whole test. - There were no differences in NEFA concentrations in the con. trol and the early pregnant group. - NEFA levels were the highest in late pregnancy. - The hypothesis we have considered to explain these variations is a double one. It brings into play an enzymatic destruction of insulin by the placenta early in pregnancy. At this time the CGP-HPI levels are not yet sufficient to exhibit an antagonistic action on the maternal glucose tolerance. This would induce a pancreatic hyperplasia very early during pregnancy. This hyperplasia helps to explain why, after the same glucose stimulus, the insulin response is transiently higher during early pregnancy. The increase in circulating insulin would explain the improvement of the glucose tolerance noted at this time. - On the contrary, in late pregnancy, the high levels of CGP-HPL increase the NEFA levels to a maximum, and consequently lower the tissue utilisation of glucose. The insulin produced in greater quantity is deviated from its usual utilization and remains at a higher level and for a longer period in the circulation.

Effet de la grossesse normale sur l'assimilation du glucose, sur les taux d'insuline et d'acides gras non estérifiés

Résumé. Des dosages d'insuline et d'acides gras non estérifiés (NEFA) ont été pratiqués dans un groupe témoin non gravide, en début et en fin de grossesse normale après injection de glucose par voie intraveineuse. - En début de grossesse, il existe déjà une réponse insulinique supérieure à celle du groupe témoin. Cette différence ne persiste pas au-delà de la $6 e$ minute de l'épreuve. - En fin de grossesse, la riposte insulinique est la plus élevée et reste élevée pendant toute l'épreuve. - Les NEFA sont aug. mentés en fin de grossesse et ne diffèrent pas du groupe témoin en début de grossesse. - L'hypothèse envisagée pour expliquer ces variations est double. Elle fait intervenir précocement au cours de la grossesse une destruction enzymatique de l'insuline par le placenta. Ceci à un moment où les taux de CGP.HPL ne sont pas encore suffisamment élevés pour exercer une action antagoniste sur la tolérance glucosée maternelle. Cette destruction plus importante provoquerait une hyperplasie et une hyperactivité des îlots de Langerhans précocement au cours de la grossesse. Ceci permettrait de comprendre pourquoi, après un même stimulus glucosé, la réponse insulinique est, en début de grossesse, transitoirement plus élevée. L'augmentation de l'insuline circulante ex- pliquant, à son tour, l'amélioration de la tolérance glucidique enregistrée à ce moment. En fin de grossesse par contre, les taux élevés de CGP-HPL augmentant au maximum le taux des NEFA, diminuent l'utilisation tissu. laire du glucose. L'insuline élaborée en plus grande quan tité, déviée de son utilisation métabolique habituelle, persistera à des doses plus élevées pendant un temps plus long dans la circulation.

Auswirkungen der normalen Schwangerschaft auf die Glucoseaufnahme und die Konzentrationen des Insulins und der freien Fettsäuren im Blut

Zusammenfassung. Bestimmungen des Insulins und der nichtveresterten Fettsäuren wurden bei einer Kontrollgruppe sowie im Beginn und am Ende normaler Schwangerschaften nach vorheriger intravenöser Glucosebelastung vorgenommen. - Am Anfang der Schwangerschaft wurde ein stärkerer Anstieg des Insulingehaltes als bei Kontrollpersonen beobachtet. Nach der 6. Minute glich er sich aus. - Am Ende der Schwangerschaft war der Anstieg des Insulinspiegels am ausgeprägtesten. Er blieb während des ganzen 'Testes erhöht. - Im Beginn der Schwangerschaft entsprachen die Werte der nichtveresterten Fettsäuren denen der Vergleichsgruppe, hin. gegen waren sie am Ende der Schwangerschaft erhöht. Dio Hypothese, mit der wir diese Beobachtungen zu erklären versuchen, betrifft zwei verschiedene Mechanismen. Einerseits nehmen wir an, daß der durch die Placenta bedingte enzymatische Insulinabbau schon früh während der Schwangerschaft wirksam wird. Zu diesem Zoitpunkt sind die CGP-HPL-Spiegel noch zu niedrig, um eine antagonistische Wirkung auf die mütterliche Glucosetoleranz auszuüben. Dieser enzymatische Insulinabbau würde eine Hyperplasie und Hyperaktivität der Langerhans'schen Inseln bedingen. Hierdurch wäre die Tatsache, daß die gleiche Glucosebelastung im Anfang der Schwangerschaft vorübergehend eine stärkere Insulinsekretion verursacht, verständIich. Der höhere Insulinspiegel im Kreislauf würde die Verbesserung der Glucosetoleranz zu diesem Zeitpunkt erklären. - Andererseits verursachen am Ende der Schwangerschaft die hohen CGP-HPL-Werte einen maximalen Wert der nichtveresterten Fettsäuren. Dieser verursacht seinerseits wieder eine Verminderung der Glucoseutilisation in den Geweben. Das in größeren Mengen sezernierte und in seiner natür. lichen Stoffwechselwirkung behinderte Insulin verbleibt somit länger und in höherer Konzentration im Kreislauf.

Key-words: Normal pregnancy: early and late glucose tolerance, intravenous glucose tolerance test, radioimmunological insulin (I.R.I.), non-esterified fatty acids (N.E.F.A.), human placental lactogen, chorionic growth hormone prolactin, insulin destruction, pancreas, placenta.
In a series of previous papers $[19,20]$ we had independently shown variations in the fasting level of blood glucose and in the utilization of this sugar by the peripheral tissue during the normal human pregnancy. The same findings have been published by others $[2$, $24,25]$. 
A significant decrease of the fasting level of blood glucose is to be found during the second and third trimester when compared with the level on the 5th day post-partum. The mild decrease observed during the first trimester was not statistically significant.

When an intravenous glucose tolerance test, carried out according to CONARD [7], was performed a significant increase in the glucose assimilation coefficient $(\mathrm{K})$ was observed in the first trimester, returning gradually during the second and third trimesters to values similar to the non-pregnant state.

In order to appreciate the eventual interference of placental factors in these variations we have studied the evolution of intravenous glucose tolerance test immediatly after delivery. A significant increase of glucose assimilation was found on the 2 nd and 3 rd days post-partum [21].

To get more information on these variations we have determined the levels of plasma insulin and nonesterified fatty acids (NEFA) in the same experimental conditions.

\section{Material and Methods}

Three groups of 9 women aged between 18 and 41 (mean age 25) were examined. One group was nonpregnant (mean height $161.7 \mathrm{~cm}$; mean weight $56.2 \mathrm{~kg}$ ). The second group was in the first trimester of pregnancy (mean height $158.6 \mathrm{~cm}$; mean weight $57 \mathrm{~kg}$ ). The third group was in the last trimester (mean height $157.7 \mathrm{~cm}$; mean weight $63.5 \mathrm{~kg}$ ). Their histories gave no evidence of diabetes. There was no glucosuria and there were no stigmas of diabetes in the past obstetric performance of multigravidas or in the outcome of current pregnancies in primigravidas. Their diet was not restricted as regards carbohydrates. The test was usually performed on ambulatory patients after a fasting period of 12 hours.

The glucose stimulation consisted of a fast intravenous injection of $0.33 \mathrm{~g}$ of glucose $(50 \%$ aqueous solution) per $\mathrm{kg}$ of body weight.

Samples for the radioimmunological assay of blood insulin were taken every minute for the first four minutes, every other minute until the tenth minute, then usually at the 30 th and 60 th minutes of the test. and Lazarow [17]. Samples were taken for the assay of NEFA at times 0,30 and 60 minutes and were collected in heparinized glass vials, which were kept at $+4^{\circ} \mathrm{C}$ until centrifugation at the end of the test. The assay was performed following the method of DoLE [8].

The statistical method used was the $T$ test of Student.

\section{Results}

The mean glucose coefficients in the pregnant groups were found to be identical with those observed previously: $K=3.1$ in early pregnancy, and $K=1.5$ in late pregnancy. However the non-pregnant group had values somewhat higher than those found for the normal population: $K=2.9$.

a) Plasma insulin (Fig. 1). The basal levels of insulin did not show significant variations during pregnancy.

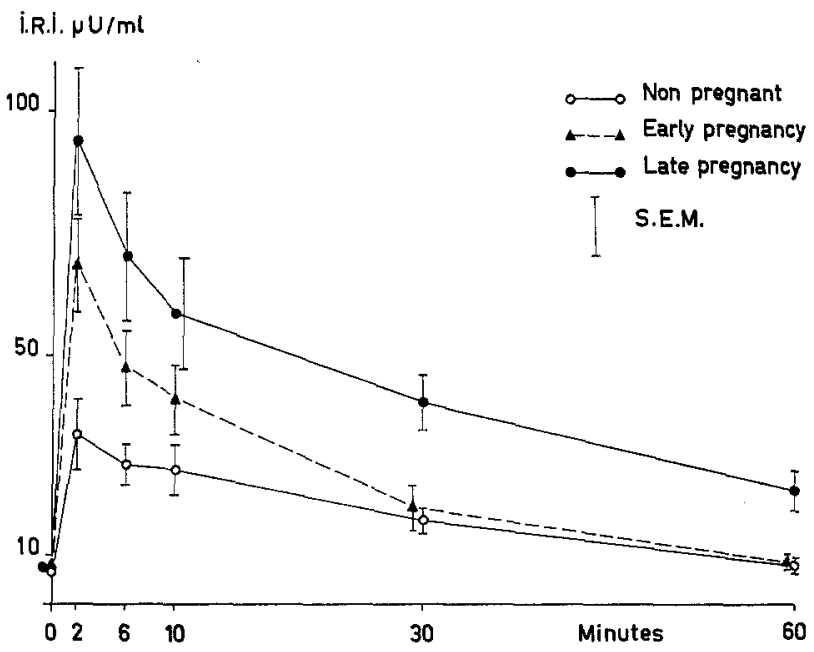

Fig. 1. Plasma Insulin Levels during normal Pregnancy. Mean plasma I. R. I. after I.V. injection of glucose $(0.33$ $\mathrm{g} / \mathrm{kg}$ b. w.) for non-pregnant, early and late-pregnant subjects. The brackets represent the standard error of the mean. There is already a transiently elevated insulin response in early pregnancy. In late pregnancy, insulin levels remain augmented during the whole test. The significance of the differences between the groups at each time are as follows:

\begin{tabular}{lllllll}
\hline Time (min) & $0^{\prime}$ & $2^{\prime}$ & $6^{\prime}$ & $10^{\prime}$ & $30^{\prime}$ & $60^{\prime}$ \\
\hline $\begin{array}{l}\text { Non-pregnant - } \\
\text { early pregnancy }\end{array}$ & N.S. $P<0.01$ & $P<0.05$ & N.S. & N.S. & N.S. \\
$\begin{array}{l}\text { Non-pregnant }- \\
\text { late pregnancy }\end{array}$ & N.S. $P<0.005$ & $P<0.01$ & $P<0.05$ & $P<0.005$ & $P<0.01$ \\
$\begin{array}{l}\text { Early pregnancy - } \\
\text { late pregnancy }\end{array}$ & N.S. N.S. & N.S. & N.S. & $P<0.05$ & $P<0.05$ \\
\hline
\end{tabular}

Samples, which were collected in heparinized glass vials, were centrifuged within two hours after the test, and the supernatant heparinized plasma was kept frozen at $-20^{\circ} \mathrm{C}$ until assay. This was performed following the double antibody technique of MoRGaN
The maximum response to the intravenous injection of glucose was observed within three minutes. Compared with the non-pregnant state, the maximum insulinic response in the early-pregnancy group was significantly higher than in the non-pregnant state, 
whereas from the tenth minute onwards the insulin levels were no longer significantly different.

In the late-pregnancy group the immediate response was higher still, and the insulin values remained significantly elevated during the whole test.

b) Non-esterified fatty acids (NEFA) (Fig. 2). As others have shown previously [5] we found that NEFA levels increased principally during the second half of pregnancy.

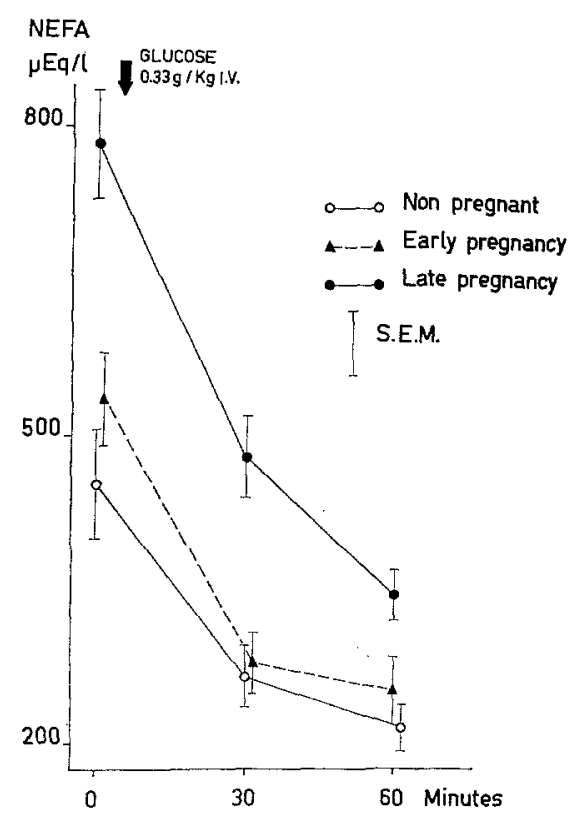

Fig. 2. Plasma NEFA Levels during normal Pregnancy. Mean plasma NEFA after a rapid I.V. injection of glucose $(0.33 \mathrm{~g} / \mathrm{kg} \mathrm{b}$.w.) for non-pregnant, early and late pregnant subjects. The brackets represent the standard error of the mean. NEFA are only elevated in late pregnancy. The significances of the differences between the groups at zero time are:

$0^{\prime}$ Non-pregnant - Early pregnancy not significant

$0^{\prime}$ Non-pregnant - Late pregnancy $\quad P<0.0005$

$0^{\prime}$ Early pregnancy - Late pregnancy $P<0.005$

In all three groups the decrease of NEFA levels under the influence of glucose stimulus, when plotted against the fasting level fall within the fiducial limits of the $95 \%$ distribution area [1]. This means that pregnancy has no significant bearing on this process (Fig. 3).

\section{Discussion}

Since the publications of CAHILL [6] and SoELDNER and Stone [26] it is well known that, in man, the increase of the plasma insulin occurs within the first. minutes of the intravenous injection of glucose.

However, this was not realized by Gowrz et al. [27, 28, 29], BuRT et al. [4], BLETCHER et a1. [2], who studied the blood insulin levels during pregnancy no earlier than 10 or 15 minutes after the intravenous glucose administration. Because of their timing, the early and sharp rise of the plasma insulin had not been noticed. Moreover BLEICHER and BuRT did not explore the early-pregnancy state.

We may set forth now the following sequence of facts:

in early pregnancy there is an increased glucose tolerance, and an early and transitory increase of plasma insulin, without a significant elevation of plasma NEFA;

in late pregnancy the glucose tolerance has returned to the non-pregnant values, with increased plasma insulin and plasma NEFA throughout the test.

When attempting to explain this sequence two different observations have to be mentioned.

On the one hand, since the work of FREINKEL and Goopner $[9,10]$ it is known that the placenta contains an enzymatic system responsible of the destruction of insulin.

On the other, JosImovich [13], KaPLAN and GRUMBAOH $[11,14]$ and more indirectly BreICHER et al. [3] have shown that the placenta secretes a lipolytic substance, called Human Placental Lactogen (HPL) by the first author, and Chorionic Growth HormoneProlactin (CGP) by the second authors. This hormone would have properties similar to pituitary growth hormone, namely an antagonistic effect on glucose metabolism. It seems not to be secreted into the foetus [16].

Our findings on the early hyperinsulinism are in accordance with the observed $\beta$-cell hyperplasia [23] and the increased insulin granulations [12] that occur in maternal pancreas during normal late pregnancy.

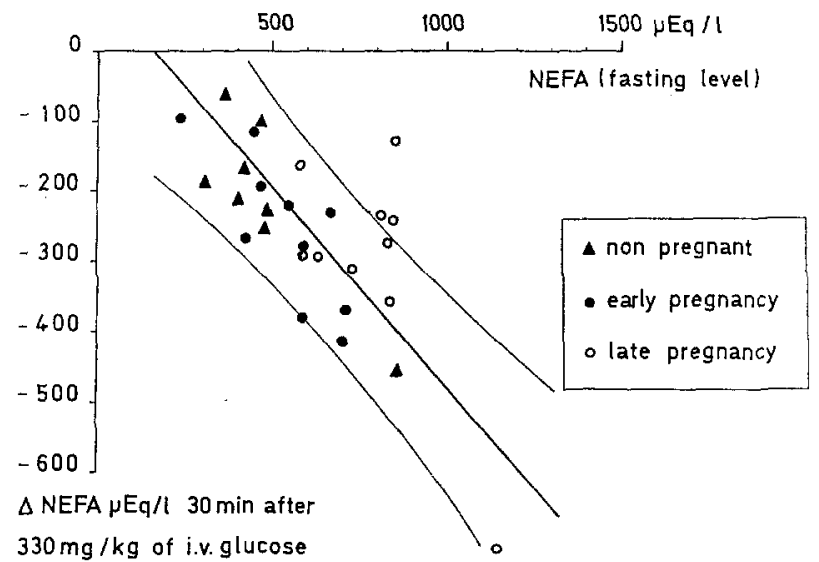

Fig. 3. Zero time NEFA and Fiducial Limits during normal Pregnancy. Decrease in absolute values of NEFA levels platted against fasting levels for non-pregnant, early and late pregnant subjects. Fiducial limits of normal values are represented.

This compensatory mechanism could be a response to an enzymatic destruction of insulin by the placenta occuring very early in pregnancy, at a time where the CGP levels are not high enough to have a significant inhibitory effect on glucose metabolism [14]. This hypothesis would explain why after the same glucose stimulus the insulin response by the increased hyper- 
trophied $\beta$-cells is transiently higher during early pregnancy with a fast return to normal values. This increase of insulin in the circulation should explain the increased utilization by tissue of glucose.

In late pregnancy, on the contrary, the increase of CGP elevates maximally the level of NEFA [11] and correlatively diminishes the utilization of glucose by the peripheral tissue [22]. The plasma insulin being thus inhibited in its metabolic activity, remains at higher levels and for a longer time in the circulation.

\section{Bibliographie}

1. Balasse, E.: Rôle du métabolisme glucidique dans la régulation des acides gras libres plasmatiques. Journées Annuelles de Diabétologie de l'Hôtel-Dieu, p. $13-22$ (1966).

2. Bleicher, S. J., J.B. O'Suluivan, and N. Freinkel: Carbohydrate metabolism in pregnaney $V$. The interrelations of glucose, insulin and FFA in late pregnancy and post-partum. New Engl. J. Med. 271, $866-872$ (1964).

3. - CH. F. Moldow, J. ScherRer, and M. G. GOEDNER : A lipid-mobilizing substance in the serum of the pregnant women of probable placental origin. Metabolism 13, 583-586 (1964).

4. BURT, R.L., and N.H. Leake: Insulin like activity in serum during pregnancy. Diabetes 11, 419-421 (1962).

5. - Plasma NEFA in normal pregnancy. Obstet. and Gynec. 15, 460-463 (1960).

6. Cahill, G.F.: Pathophysiology of diabetes. Med. Clin. N. Amer. 49, 881-891 (1965).

7. Conard, V.: Mesure de l'assimilation du glucose. Acta med. belg. I, Thesis (1955).

8. Dole, V.P.: A relation between non-esterified fatty acids in plasma and the metabolism of glucose. $J$. clin. Invest. 35, 150-154 (1956).

9. Freinkmu, N., and CH. Goodner: Carbohydrate metabolism in pregnancy $I$. The metabolism of insulin by human placental tissue. J. clin. Invest. 39, $116-131(1960)$.

10. - - Insulin metabolism in pregnancy. Arch. intern. Med. 109, 163-172 (1962).

11. Grumbach, M.M., S.L. Kaplan, C.L. Abrams, J.J. BeLL, and F.A. Conte: Plasma free fatty acid res. ponse to the administration of chorionic "GrowthHormone-Prolactin". J. clin. Endocr. 26, 478-482 (1966).

12. Hellman, B.: The islets of Langerhans in the rat during pregnancy and lactation with special reference to the changes in the $\mathrm{B} / \mathrm{A}$ cells ratio. Acta obstet. gynee. scand. 39, 331-342 (1960).

13. Josmovitch, M.B., and J.A. McLaren: Presence in the human placenta and term serum of highly lactogenic substance immunologically related to pituitary G.H. Endocrinology 71, 209-220 (1962).

14. KaPLAN, S.L., and M.M. GRUMBBACH: Immunoassay for human chorionic "growth hormone prolactin" in serum and urine. Science 147, $751-753$ (1965).

15. - - Studies of a human and simian placental hormone with growth hormone-like and prolactin-like activities. J. clin. Endocr. 24, 80-100 (1964).

16. - - Serum chorionic "growth hormone prolactin" and serum pituitary growth hormone in mother and fetus at term. J. clin. Endocr. 25, 1370-1374 (1965).

17. Morgan, C.R, and A. Lazarow: Immunoassay of insulin. Diabetes 12, 115-126 (1963).

18. - R.L. Sorenson and A. Lazarow: Further studies of inhibitory of the two antibody immunoassay systems. Diabetes 13, 579-584 (1964).

19. Picard, C., K. OosterwiJck, and V. Conard : Etude de l'assimilation glucidique des gestantes normales et probablement prédiabétiques. $\mathrm{XIXe}$ Congrès Nancy. Bull. Féd. Gynéc. Obstét. franç. 13, 529535 (1961).

20. - P. Preumont, and E. Rothschild : Analyse des résultats de l'épreuve d'hyperglycémie intraveineuse pendant la grossesse. XXe Congrès, Lille. Bull. Féd. Gynéc. Obstét. franç. 15, 249-253 (1963).

21. - Ch. Ehman, and V. Conard: Influence du postpartum et de la lactation sur l'assimilation glucidique. Rev. franç. Ét. clin. biol. 11, $531-532$ (1965).

22. Randle, P.J., P.B. Garland, C.N. Hales and E.A. Newsholme: The glucose fatty-acid cycle. Its role in insulin sensitivity and the metabolic disturbances of diabetes mellitus. Lancet $1963 \mathrm{I}, 785-790$.

23. Rosentoecher, L.: Die Veränderungen des Pancreas in der Schwangerschaft bei Mensch und Tier. Arch. Gynäk. 151, 567-575 (1932).

24. Silverstone, F.A., E. Solomons, and J. Rubricus: The rapid intravenous glucose tolerance test in pregnancy. J. clin. Invest. 40, 2180-2189 (1961).

25. - - - The rapid glucose tolerance test in obstetrical patients with a family history of diabetes. Diabetes 12, 398-405 (1963).

26. SoELdNER, J.S., and D. SLone: Critical variables in the radioimmunoassay of serum insulin using the double antibody technique. Diabetes 14, $771-779$ (1965).

27. Spellacy, W.N., F.C. Goetz, M. S. Greenderg, and J. ELLs: Plasma insulin in normal early pregnancy. Obstet. and Gynec. 25, 862-865 (1965).

28. - - - Plasma insulin in normal mid-pregnancy. Amer. J. Obstet. Gynec. 92, 11-15 (1965).

29. - - Plasma insulin in normal late pregnancy. New Engl. J. Med. 268, 988-991 (1963).

Dr. C. Picard

Hôpital Universitaire Saint Pierre

322, rue Haute

Bruxelles, Belgique 